\title{
STUDI KARAKTERISTIK HASIL FERMENTASI OLAHAN BENGKOANG (Pachyrizus erosus ) MENGGUNAKANBERBAGAI KONSENTRASI RAGI
}

\author{
Purnama Dini Hari, Wenny Surya Murtius, dan Ira Desri Rahmi \\ Program Studi Teknologi Hasil Pertanian Universitas Andalas \\ Email: purnamadini@fateta.unand.ac.id
}

\begin{abstract}
ABSTRAK
Bengkoang (Pachyrizus erosus) adalah tanaman berumbi yang banyak ditanam di Kota Padang. Umbi umumnya dikonsumsi mentah. Untuk itu diperlukan pengolahan lanjut sebagai diversifikasi produk. Penelitian mengenai karakter hasil fermentasi olahan Bengkoang (Pachyrizus erosus) menggunakan berbagai konsentrasi ragi telah dilaksanakan pada bulan Mei - Juli 2017. Penelitian tersebut bertujuan untuk mengetahui karakter fisik, kimia dan mikrobiologi hasil fermentasi Bengkoang menggunakan ragi pada berbagai konsentrasi. Hasil olahan bengkoang yang menjadi objek antara lain bubur, sari dan konsentrat. Sementara konsentrasi ragi yang digunakan adalah 1\%, 2\%, 3\% dan 4\% dari berat objek. Dari hasil penelitian diperoleh kadar air berkisar 84,66 \% - 96,5\%, pH 3,8 - 4,37, total gula $1,548 \%$ - 11,375\% , gula pereduksi $0,0003 \%-4,88 \%$ total bakteri asam laktat (BAL) 7,38 - 8,46 Log CFU/g dan kadar alkohol $1,06 \%-3,03 \%$. Total BAL, total gula, gula pereduksi menunjukkan potensi produk bengkoang fermentasi untuk dibuat minuman dengan manfaat probiotik. Namun demikian diperlukan penelitian lanjutan untuk mengetahui lebih lanjut mengenai hal tersebut.

Kata kunci- bengkoang; fermentasi; ragi
\end{abstract}

\section{PENDAHULUAN}

Tanaman Bengkoang (Pachyrizus erosus) adalah tanaman yang dibudidayakan secara luas. Salah satu daerah yang menjadi penghasil Bengkoang di Sumatera Barat adalah Kota Padang. Diketahui bahwa luas lahan yang digunakan di kota Padang untuk bertanam Bengkoang cenderung meningkat setiap tahunnya (BPS, 2013). Bengkoang asal Kota Padang juga telah ditetapkan sebagai varietas unggul sesuai Surat Keputusan Menteri Pertanian nomor 275/Kpts/SR.120/M/7/2005. Varietas tersebut memiliki keunggulan antara lain produktivitas tinggi, umur genjah, umbi besar, rasa umbi manis, tekstur umbi renyah, kulit umbi mudah dilepas dari dagingnya, dan beradaptasi baik di dataran rendah.

Bengkoang dibudidayakan untuk diambil umbinya. Umbi tersebut secara umum memiliki kadar air yang tinggi. Umbi juga mengandung karbohidrat, protein, vitamin dan mineral (USDA, 2016). Selain itu Bengkoang juga mengandung banyak enzim yang menyebabkan degradasi komponen gizi dan kerusakan tekstur yang relatif cepat. Hal ini menyebabkan Bengkoang tidak bisa disimpan dalam bentuk segar pada waktu yang relatif lama.

Bengkoang pada umumnya dikonsumsi dalam bentuk mentah. Dalam keadaan tersebut Bengkoang bisa berperan sebagai sumber serat dan mineral yang baik untuk tubuh. Namun demikian, masih dibutuhkan penambahan rasa manis untuk meningkatkan penerimaan konsumen. Hal tersebut bisa dilakukan dengan memanfaatkan potensi karbohidrat di dalamnya untuk menjadi gula sederhana ( de-la-Pena et. al, 2013).

Pembuatan sirup gula dari Bengkoang bisa dilakukan secara enzimatis, yaitu dengan menambahkan enzim seperti pektinase. Persentase hasil yang didapatkan relatif tinggi. de-la-Pena et. al (2012) melaporkan jumlah glukosa yang bisa dibebaskan mencapai 7,58 \%. Namun demikian, penggunaan enzim membutuhkan biaya yang relatif besar.

Penggunaan mikroba sebagai penghasil enzim telah dilakukan sejak lama. Pemakaian mikroba dirasa memberikan biaya yang relatif murah dibandingkan menggunakan enzim murni. Salah satu sumber mikroba yang murah adalah ragi. Ragi adalah starter yang sering digunakan untuk pembuatan makanan tradisional seperti tapai ketan dan tapai ketela. Ragi yang umum dijual berbentuk seperti koin dengan diameter lebih kurang $3 \mathrm{~cm}$, berwarna putih kekuningan dan berbau khas tepung.

Adapun tujuan dari penelitian ini adalah untuk mengetahui karakter fisik, kimia dan mikrobiologi hasil fermentasi Bengkoang menggunakan ragi pada berbagai konsentrasi. 


\section{A. Bahan}

\section{METODOLOGI PENELITIAN}

Bahan yang digunakan adalah Bengkoang dan ragi tradisional yang dibeli di pasar terdekat.

\section{B. Pembuatan Produk}

Produk diolah dengan metoda kombinasi de-la-Pena (2013) dengan Han dan Park (2015) yang dimodifikasi. Umbi Bengkoang dikupas dan dicuci dengan air mengalir, ditimbang lalu dipotong berbentuk kubus dengan ukuran lebih kurang 1x1x1 cm. Kemudian diblansir menggunakan autoklaf pada tekanan 146,9kPa selama 10 menit dan digiling sampai membentuk bubur (B). Bubur bengkoang kemudian dicampur air dan diperas untuk mendapatkan sarinya (S). Sari Bengkoang kemudian dipekatkan hingga setengah volume awal menggunakan rotary evaporator (konsentrat/K). Bubur, sari dan konsentrat kemudian dipasteurisasi lalu didinginkan. Kemudian ditambahkan ragi dengan konsentrasi $1 \%, 2 \%, 3 \%$ dan $4 \%$ untuk difermentasi selama 24 jam.

\section{Rancangan}

Penelitian menggunakan pendekatan eksploratif dengan mencoba dua parameter, yaitu produk olahan bengkoang (bubur, sari, dan konsentrat) sebagai parameter pertama dan konsentrasi ragi $(1 \%, 2$ $\%, 3 \%$ dan $4 \%$ ) sebagai parameter kedua. Setiap satuan percobaan dilakukan triplo. Data ditampilkan dalam rata-rata dengan standar deviasi.

\section{Analisa Produk}

Pengamatan dilakukan terhadap bahan baku. Pengamatan juga dilakukan terhadap bubur, sari dan konsentrat pra dan pasca fermentasi. Analisa yang dilakukan antara lain kadar air (AOAC, 1997), pH (AOAC, 1997), total gula (Nielsen, 2010), dan gula pereduksi (Nielsen, 2010) untuk semua tahapan. Analisa lainnya yaitu total alkohol (Nielsen, 2010) dan bakteri asam laktat (Goldman dan Green, 2009) untuk bubur, sari dan konsentrat pasca fermentasi. Sebagai tambahan juga diamati karakteristik produk fermentasi yang dihasilkan (aroma, warna, dan adanya gas)

\section{HASIL DAN PEMBAHASAN}

Penelitian ini telah dilakukan pada bulan Mei sampai Juli tahun 2017 di Laboratorium Mikrobiologi dan Bioteknologi, dan Laboratorium Kimia dan Biokimia Hasil Pertanian Program Studi Teknologi Hasil Pertanian, serta Laboratorium Instrumentasi Fakultas Teknologi Pertanian Universitas Andalas Padang. Data kadar air, $\mathrm{pH}$, total gula, dan gula pereduksi pada bahan baku dan bahan sebelum fermentasi dapat dilihat pada Tabel 1.

Tabel 1. Hasil Pengamatan Bahan Baku dan Pra Fermentasi

\begin{tabular}{lcccc}
\hline \multicolumn{1}{r}{ Sampel } & Kadar air (\%) & Ph & Total Gula (\%) & Gula Pereduksi (\%) \\
\hline Umbi & $87,05 \pm 4,353$ & - & - & - \\
Bubur & - & $6,64 \pm 0.332$ & $1,687 \pm 0,085$ & $0,00015 \pm 0$ \\
Sari & - & $6,91 \pm 0.345$ & $1,299 \pm 0,067$ & $0,0001 \pm 0$ \\
Konsentrat & - & $5,85 \pm 0.294$ & $2,375 \pm 0,122$ & $0,465 \pm 0.023$ \\
\hline
\end{tabular}

Rata-rata kadar air bahan baku yang didapatkan adalah $87,05 \%$. Sementara untuk total gula dan gula pereduksi secara berurutan adalah 1,687 \% dan 0,00015\%. Kadar air yang didapatkan lebih rendah dibandingkan kadar air bengkoang segar menurut Klockemen, Pressey dan Jen (1991) yaitu sebesar $89,9 \%$. Sementara total gula dari bubur lebih rendah dari standar USDA (2016) yaitu 1,8\%.

Proses penyaringan bubur bengkoang menurunkan total gula dan gula pereduksi dari sari bengkoang. Hal tersebut karena gula pada bubur tidak terpisah secara sempurna dan masih ada yang terbawa bersama ampas. Naiknya total gula dan gula pereduksi pada konsentrat karena efek pemekatan. Proses pemekatan yang dilakukan melibatkan panas. Kawabata, Sawayama, Rosario dan Noel (1986) menyatakan bahwa umbi berpati memiliki kecenderungan tersebut saat diberi perlakuan panas. 
Tingkat keasaman bahan sebelum fermentasi berkisar 5,85 sampai 6,91. $\mathrm{pH}$ tersebut berada dalam kisaran $\mathrm{pH}$ netral. Berdasarkan $\mathrm{pH}$, maka ketiga bahan dasar telah cocok dijadikan substrat pertumbuhan mikroba. Hogg (2005) menyatakan bahwa mayoritas mikroba tumbuh baik pada kisaran $\mathrm{pH}$ netral (pH 7).

Proses fermentasi dilakukan selama 24 jam dalam wadah botol yang ditutup rapat. Secara umum, ciri sensoris dari produk adalah berwarna putih dan memiliki aroma bawang putih. Adanya aroma ini disebabkan oleh adanya bawang putih yang terdapat pada komposisi ragi yang digunakan. Semua sampel pasca fermentasi terindikasi mengandung gas. Hal ini sesuai dengan pendapat Hogg (2005) bahwa proses metabolisme mikroba, salah satunya respirasi pada akhirnya akan menghasilkan gas $\mathrm{CO}_{2}$.

Adapun hasil pengamatan terhadap kadar air, $\mathrm{pH}$, total gula dan gula pereduksi produk dapat dilihat pada Tabel 2. Sementara hasil pengamatan total bakteri asam laktat dan total alkohol dapat dilihat pada Tabel 31

Tabel 2. Hasil Pengamatan produk fermentasi

\begin{tabular}{cccll}
\hline Sampel & Kadar air $(\%)$ & \multicolumn{1}{c}{$\mathbf{p H}$} & \multicolumn{1}{c}{ Total Gula (\%) } & Gula Pereduksi (\%) \\
\hline B1 & $84,66 \pm 4,23$ & $4,22 \pm 0,21$ & $1,694 \pm 0,085$ & $0.0004 \pm 0$ \\
B2 & $83,64 \pm 4,18$ & $3,82 \pm 0,19$ & $2,055 \pm 0,103$ & $0.0006 \pm 0$ \\
B3 & $82,66 \pm 4,13$ & $3,84 \pm 0,19$ & $2,073 \pm 0,104$ & $0.00085 \pm 0$ \\
B4 & $81,70 \pm 4,09$ & $3,80 \pm 0,19$ & $2,304 \pm 0,115$ & $0,01 \pm 0,0005$ \\
S1 & $96,50 \pm 4,83$ & $3,98 \pm 0,2$ & $1,548 \pm 0,077$ & $0.0003 \pm 0$ \\
S2 & $95,14 \pm 4,76$ & $3,87 \pm 0,19$ & $1,631 \pm 0.082$ & $0.0005 \pm 0$ \\
S3 & $94,87 \pm 4,74$ & $3,85 \pm 0,19$ & $1,845 \pm 0.09$ & $0.00075 \pm 0$ \\
S4 & $94,47 \pm 4,72$ & $3,82 \pm 0,19$ & $2,225 \pm 0,10$ & $0.0009 \pm 0$ \\
K1 & $93,46 \pm 4,67$ & $4,37 \pm 0,22$ & $3,5 \pm 0,18$ & $1.615 \pm 0,081$ \\
K2 & $92,97 \pm 4,65$ & $4,36 \pm 0,22$ & $5,75 \pm 0,29$ & $2.98 \pm 0,16$ \\
K3 & $92,41 \pm 4,62$ & $4,36 \pm 0,22$ & $7,875 \pm 0,4$ & $2.46 \pm 0,14$ \\
K4 & $91,69 \pm 4,58$ & $4,30 \pm 0,22$ & $11,375 \pm 0,57$ & $4.88 \pm 0,26$ \\
\hline
\end{tabular}

Keterangan: $\mathrm{B}=$ bubur, $\mathrm{S}=$ sari, $\mathrm{K}=$ konsentrat, sementara angka adalah penambahan ragi yaitu $1=1 \%$, $2=2 \%, 3=3 \%$ dan $4=4 \%$

Secara umum, terjadi peningkatan total gula, gula pereduksi dan penurunan $\mathrm{pH}$ fermentasi. Bakteri asam laktat ditemukan dalam konsentrasi yang relatif tinggi, begitu pula total alkohol. Kegiatan fermentasi didefinisikan sebagai kegiatan mikrobiologis untuk memecah substrat organik untuk menghasilkan energi tanpa bantuan rantai transpor elektron (Stanbury, 2003). Kegiatan ini mempunyai dua jalur. Jalur pertama menghasilkan asam laktat, dan jalur kedua menghasilkan etanol. Ragi yang menjadi starter adalah starter tradisional. Starter tersebut mengandung mikroba yang heterogen yaitu kapang, khamir dan bakteri (Abe, 2004). Mikroba tersebut akan menghasilkan metabolit yang bisa saja berbeda-beda.

Kadar air yang didapatkan berkisar 84,66 \% sampai 96,5\%. Kadar air tertinggi diperoleh dari sari, diikuti oleh konsentrat. Kadar air yang rendah pada bubur bengkoang dibandingkan produk lainnya adalah karena pada sari masih terdapat komponen karbohidrat yang berbentuk padat. Hal inilah yang membuat persentase air pada bahan menjadi relatif lebih rendah dibandingkan sari dan konsentrat. Peningkatan kadar air setelah fermentasi diperkirakan oleh kegiatan respirasi mikroba. Respirasi diketahui memberikan hasil akhir salah satunya adalah air.

Hogg (2005) menyatakan bahwa selama proses pertumbuhan mikroba, pH lingkungannya akan mengalami penurunan akibat aktivitas metabolisme mikroba tersebut. hal ini sesuai dengan hasil yang didapat, yaitu telah terjadi penurunan $\mathrm{pH}$ dari kisaran netral (mendekati 7$)$ menuju $\mathrm{pH}$ asam $(<5,5)$. Penurunan $\mathrm{pH}$ diperkirakan karena aktivitas metabolisme bakteri asam laktat.

Total gula dan gula pereduksi produk cenderung mengalami kenaikan. Hal ini kemungkinan karena hidrolisis pati yang terdapat pada bengkoang menjadi molekul yang lebih kecil. Hidrolisis pati dapat disebabkan oleh enzim yang diproduksi oleh mikroba (Joshi, 2016).

Total BAL dari hasil fermentasi berkisar antara 7,38 - 8,46 Log CFU/g. Jumlah ini telah memenuhi SNI 2981:2009 yogurt, yaitu minimal bakteri 7,00 Log CFU/g. jumlah BAL yang relatif 
tinggi disebabkan oleh tersedianya nutrisi yang mencukupi bagi BAL pada bengkoang. BAL diketahui mengkonsumsi monosakarida, namun bervariasi jenisnya tergantung spesies (Joshi, 2016). BAL juga diketahui mengkonsumsi oligosakarida, salah satu contohnya yaitu inulin (Kolida, S, Tuohy K. dan G.R. Gibson, 2002). Inulin terdapat pada Bengkoang dengan jumlah lebih dari 10\% (Wimala, M., Retaningtyas, Y. dan L. Wulandari, 2015).

Tabel 3. Hasil pengamatan total bakteri asam laktat (BAL) dan kadar alkohol produk fermentasi

\begin{tabular}{lll}
\hline Sampel & $\begin{array}{c}\text { Total BAL } \\
(\mathbf{L o g} \mathbf{C F U / g})\end{array}$ & $\begin{array}{c}\text { Kadar alkohol } \\
(\boldsymbol{\%})\end{array}$ \\
\hline B1 & $7,380 \pm 0,369$ & $1,06 \pm 0,053$ \\
B2 & $7,398 \pm 0,37$ & $1,33 \pm 0,067$ \\
B3 & $7,415 \pm 0,37$ & $1,53 \pm 0,077$ \\
B4 & $8,176 \pm 0,41$ & $1,80 \pm 0,09$ \\
S1 & $8,079 \pm 0,40$ & $1,33 \pm 0,068$ \\
S2 & $8,230 \pm 0,41$ & $1,53 \pm 0,076$ \\
S3 & $8,230 \pm 0,41$ & $1,86 \pm 0,093$ \\
S4 & $8,279 \pm 0,41$ & $2,14 \pm 0,11$ \\
K1 & $8,230 \pm 0,41$ & $2,20 \pm 0,11$ \\
K2 & $8,322 \pm 0,41$ & $2,46 \pm 0,12$ \\
K3 & $8,431 \pm 0,42$ & $2,76 \pm 0,14$ \\
K4 & $8,462 \pm 0,42$ & $3,03 \pm 0,15$ \\
\hline
\end{tabular}

Keterangan: $\mathrm{B}=$ bubur, $\mathrm{S}=$ sari, $\mathrm{K}=$ konsentrat, sementara angka adalah penambahan ragi yaitu $1=1 \%$, $2=2 \%, 3=3 \%$ dan $4=4 \%$

Ragi termasuk ke dalam starter amilolitik yang digunakan untuk fermentasi makanan atau minuman yang mengandung alkohol. Pada penelitian ini ragi digunakan sebagai starter. Hasil pengamatan menunjukkan kadar alkohol produk berkisar 1,06\% - 3,03 \% setelah fermentasi selama 24 jam. Yulianti (2014) pada penelitiannya mendapatkan total alkohol pada tapai beras, ketan hitam dan singkong berturut-turut 7,72 \%,6,95\% dan 7,12\% setelah fermentasi selama 48 jam. Hasil yang didapat pada penelitian ini hampir mencapai setengah dari penelitian tersebut. Sementara kadar karbohidrat bengkoang lebih rendah dibandingkan dengan ketiga substrat yang dibandingkan.

\section{KESIMPULAN}

Dari penelitian dapat disimpulkan bahwa fermentasi bengkoang menggunakan ragi untuk membuat tapai didapat hasil minuman fermentasi dengan ciri berwarna putih, beraroma bawang putih dan bergas. Proses fermentasi ini meningkatkan total gula dan gula pereduksi, serta menurunkan $\mathrm{pH}$. Dari fermentasi juga dihasilkan total BAL yang cocok sebagai probiotik dan alkohol. Adapun kadar air berkisar $84,66 \%-96,5 \%$, pH 3,8 - 4,37 , total gula $1,548 \%-11,375 \%$, gula pereduksi $0,0003 \%$ 4,88\% total bakteri asam laktat (BAL) 7,38 - 8,46 Log CFU/g dan kadar alkohol 1,06\% - 3,03\%.

\section{UCAPAN TERIMAKASIH}

Penelitian ini dilaksanakan dengan pendanaan dari DIPA Fakultas Teknologi Pertanian Universitas Andalas Tahun 2017.

\section{DAFTAR PUSTAKA}

Abe, A, Sujaya IN, Sone, T, Asano K dan Y Oda. 2004. Microflora and Selected Metabolites of Potato Pulp Fermented with an Indonesian Starter Ragi Tape. Food Tech. Biotechnol 42(3) 169-173.

AOAC. 1997. Official Methods of Analysis. Association of Official Analytical Chemists Inc. 
De-la- Pena, Ana M.R., Renard, Catherine M.G.C., Wicker, Louise dan Juan C. C. Esquivel. 2012. Enzymatic Liquefaction of Jicama (Pachyrizus erosus) Tuberous Roots and Characterization of The Cell Walls after Processing. LWT- Food Science and Technology 49:257-262.

2013. Review: Advances and Perspectives of Pachyrizus spp. in Food Science and Biotechnology. Trends in Food Science and Technology 29: 44-54

Goldman, Emanuel dan Lorrence H. Green. 2009. Practical Handbook of Microbiology Second Edition. CRC Press.

Hogg, S. 2005. Essential Microbiology. John Wiley and Sons.

VK Joshi. 2016. Indigenous Fermented Foods of South Asia.CRC press.

Kawabata, A., Sawayama, S., Rosario, R. R. D., dan M. G. Noel. 1986. Effect of Storage and Heat Treatments on The Sugar Constituents in Cassava and Yambean Roots. Nippon Shokuhin Kogyo Gakkaishi. 33(6) : 441-449

Klockeman, D. M., Pressey, R., dan J. J. Jen. 1991. Characterization of Cell Wall Polysaccharides of Jicama (Pachyrizus erosus) and Chinese Water Chestnut (Eleocharis dulcis). Journal of Food Biochemistry. $15:$ 317-329.

Kolida, S, Tuohy K. dan G.R. Gibson. 2002. Prebiotic Effects of Inulin and Oligofructose. British Journal of Nutrition 87, suppl. 2:193-197

Nielsen, Suzanne S. 2010. Food Analysis, Fourth Edition. Springer

Park, Chan Joo dan Ji-Sook Han. 2015. Hypoglycemic Effect of Jicama (Pachyrizus erosus) Extract on Streptozotocin-Induce Diabetic Mice. Prev. Nutr. Food Science 20(2): 88-93.

Stanbury, P.F. 2003. Principles of Fermentation Technology $2^{\text {nd }}$ Edition. Butterworth-Heinemann.

Tamang, J.P. dan K. Kailasapathy. 2010. Fermented Foods and Beverages of The World. CRC press. 